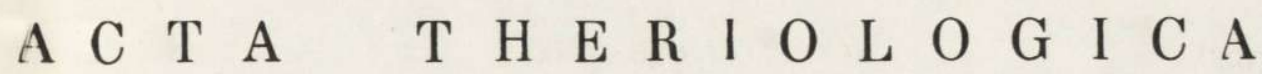

VOL. XVI, 20: 329-339.

BIAŁOWIEŻA

November, 1971

Marek G Ę B C Z Y N S K I

\section{The Rate of Metabolism of the Lesser Shrew}

\author{
[With 3 Tables \& 1 Fig.]
}

\begin{abstract}
Oxygen consumption was determined in 76 individuals of Sorex minutus. The mean daily metabolism $(A D M R)$ is higher in young, sexually immature shrews in comparison with mature overwintered animals. Also some seasonal differences are visible. The $A D M R$ at $20^{\circ} \mathrm{C}$ in young individuals amounts in summer to $14.88 \mathrm{cc} / \mathrm{g} \mathrm{hr}$, in autumn to 14.10 and in winter to 14.72 . In old adults $A D M R$ is equal in spring to $12.52 \mathrm{cc} / \mathrm{g} \mathrm{hr}$ and in summer to 11.24 . At $15^{\circ} \mathrm{C} A D M R$ in old adults amounts in spring to $13.98 \mathrm{cc} / \mathrm{g} \mathrm{hr}$, and at $10^{\circ} \mathrm{C}$ to $16.86 \mathrm{cc} / \mathrm{g} \mathrm{hr}$. The lowest recorded oxygen consumption was equal to $7.04 \mathrm{cc} / \mathrm{g} \mathrm{hr}$ (body weight $4.6 \mathrm{~g}$ ). Hence the metabolic rate of lesser shrew is similarly high as other shrews but different from rodents. Short-term measurements of oxygen consumption by $S$. minutus at different temperatures demonstrated that oxygen consumption abruptly increases below $15^{\circ} \mathrm{C}$, but changes only slightly in the range of 20 to $30^{\circ} \mathrm{C}$. Daily measurements of oxygen consumption indicate that the lesser shrew belongs to the species active all the day with a slight predominance of nocturnal activity.
\end{abstract}

\section{INTRODUCTION}

The lesser shrew, Sorex minutus Lin na e us, 1776, belongs to the smallest mammals and for this reason its metabolic rate was supposed to be extremely high. The first investigations on this species were carried out by Hawkins, Jewell \& Tomlins on (1960). They measured heat losses in one individual using a differential calorimeter. Later Hawkins \& Jewell (1962) determined the food intake in two representatives of this species. The results of these investigations proved that the rate of metabolism in $S$. minutus is indeed very high, but it does not differ significantly from that of small rodents. On the other hand, B a shenina (1965) made a short-term measurement of oxygen consumption at different ambient temperatures in 5 individuals of the lesser shrew and observed unusually strong reaction to cold.

None of the mentioned papers paid attention to the phenomenon of seasonal and age changes of shrews (D e hnel, 1949) reflected not only 
in morphological features (for references see Pucek, 1970), but also in physiological indices (G ę bczyński, 1965). Hence the present study was aimed at the measurement of oxygen consumption in the full life cycle of the lesser shrew including various seasons.

\section{MATERIAL AND METHODS}

Lesser shrews were trapped in damp biotopes of the Białowieża National Park. The trappings and measurements were carried out in the years 1963-1964 and 1966 -1970 , thus permitting for the determination of oxygen consumption in 76 shrews, including 24-hour measurements in 60 individuals.

The shrews, after they had been brought to the laboratory, were placed singly in wooden cages padded with moss and wooden shavings. The temperature in the laboratory room ranged from 15 to $19^{\circ} \mathrm{C}$. Minced meat with various additives was used as the food (W o $1 \mathrm{k}, 1969$ ).

Daily measurements of oxygen consumption by shrews were carried out in 2 to 5 days after capture and every individual was used only once. In the determinations of chemical thermoregulation, lasting 15 to $60 \mathrm{~min}$., the same shrews were used several times. Oxygen consumption was determined either by means of a closed-circuit respirometer of the Kalabukhov-Skvortzov type (G ę b c z y ński, 1963), or of the Morrison type (Morrison \& Grodziński, 1968). In daily runs 9.0 or 14.41 chambers were used. During short measurements a shrew was placed in a cage made of wire net $(2 \times 2 \times 4 \mathrm{~cm})$ in a 1 l. chamber. The method of measurements has been described in detail in the earlier paper (G ę bc zy ński, 1965).

\section{RESULTS}

\section{Daily Metabolism Rate}

Daily measurements of oxygen consumption were carried out in all seasons at the temperature of $20^{\circ} \mathrm{C}$, and in spring additionally at 10 and $15^{\circ} \mathrm{C}$ (Table 1$)$. The average daily metabolism rate $(A D M R)$ is different in particular seasons, and moreover depends on the animal age. The highest $A D M R$, expressed in $\mathrm{cc} / \mathrm{g} \mathrm{hr}$, was found for young adult individuals in summer. The value is highly significantly different (Student $t$-test, $P<0.001$ ) from that shown in the same period by overwintered old adults. The obtained results were also expressed in kilocalories assuming that $4.8 \mathrm{kcal}$ is the equivalent of $1 \mathrm{l}$ of oxygen. After this computation it was possible to conclude that the energy requirement in a young adult is higher in summer by as much as $40 \%$ when expressed per $1 \mathrm{~g}$ of body weight, in comparison with an old adult (Table 1). Since, however, the overwintered animals show at that time much higher body weight, energy requirements were further computed for the metabolic body size $\left(\mathrm{kg}^{0.75}\right)$. In this case it is clearly visible that in summer the metabolism rate in young shrews is $44 \%$ higher than in old ones (Table 1 ). 
Young adult shrews captured in autumn have a lower ADMR than those in summer, but the difference is statistically not significant. A similarly non-significant difference was found to exist for young adult shrews between winter and autumn. In overwintered animals $A D M R$ measured in spring is markedly lower than in young adults examined in winter $(P<0.01)$. Also old adults in summer show significantly lower $A D M R$ than those in spring.

Hence in young individuals of the lesser shrew $A D M R$ is considerably higher than in overwintered animals. On the other hand, young shrews do not show such seasonal differences as adult ones (Table 1). Also after computing oxygen consumption for metabolic body size young shrews differ markedly in the energy requirement from the overwintered animals (Table 1).

Table 1

Average daily metabolism rate $(A D M R)$ of the lesser shrew in different seasons. Summer - June and July, Autumn - October, Winter - January and February, Spring - April and first half of May.

\begin{tabular}{|l|c|cc|c|c|c|r|}
$\begin{array}{c}\text { Season } \\
\text { ard age }\end{array}$ & $\begin{array}{c}\text { Temp., } \\
{ }^{\circ} \mathrm{C}\end{array}$ & $\begin{array}{c}\text { Avg. body } \\
\text { wt., g }\end{array}$ & $\begin{array}{c}\text { cc/g hr } \\
\pm \mathrm{S} . \mathrm{D} .\end{array}$ & $\begin{array}{c}\mathrm{kcal} / \mathrm{g} \\
\text { per day }\end{array}$ & $\begin{array}{c}\mathrm{kcal} / \mathrm{animal} \\
\text { per day }\end{array}$ & $\begin{array}{c}\mathrm{kcal} / \mathrm{kg}^{0.75} \\
\text { per day }\end{array}$ & $\mathrm{n}$ \\
\hline $\begin{array}{l}\text { Summer } \\
\text { young ad }\end{array}$ & 20 & 2.91 & $14.88 \pm 1.44$ & 1.714 & 4.988 & 639.5 & 14 \\
$\begin{array}{l}\text { Autumn } \\
\text { young ad }\end{array}$ & 20 & 3.02 & $14.10 \pm 1.05$ & 1.624 & 4.905 & 610.1 & 8 \\
$\begin{array}{l}\text { Winter } \\
\text { young ad }\end{array}$ & 20 & 2.85 & $14.72 \pm 1.31$ & 1.697 & 4.836 & 636.3 & 4 \\
$\begin{array}{l}\text { Spring } \\
\text { old ad }\end{array}$ & 20 & 4.04 & $12.52 \pm 0.89$ & 1.442 & 5.827 & 485.6 & 12 \\
$\begin{array}{l}\text { Summer } \\
\text { old ad }\end{array}$ & 20 & 4.62 & $11.24 \pm 1.17$ & 1.295 & 5.982 & 443.1 & 10 \\
$\begin{array}{l}\text { Spring } \\
\text { old ad }\end{array}$ & 15 & 4.54 & $13.98 \pm 0.80$ & 1.610 & 7.311 & 558.1 & 6 \\
$\begin{array}{l}\text { Spring } \\
\text { old ad }\end{array}$ & 10 & 3.91 & $16.86 \pm 1.66$ & 1.942 & 7.596 & 677.9 & 6 \\
\hline
\end{tabular}

Additional daily measurements at 10 and $15^{\circ} \mathrm{C}$ in spring enabled drawing the conclusion that lowering ambient temperature leads to a significant increase of oxygen consumption (Table 1). This rise is more pronounced between 10 and $15^{\circ} \mathrm{C}$ than between 15 and $20^{\circ} \mathrm{C}$, because in the first case the difference amounts to $2.88 \mathrm{cc} / \mathrm{g} \mathrm{hr}$, and in the second one to $1.46 \mathrm{cc} / \mathrm{g} \mathrm{hr}$, being almost twice as high.

\section{Minimum and Maximum Oxygen Consumption Rate}

During daily runs the periods of the lowest and highest oxygen consumption were recorded. This enabled the comparison of these values 
with $A D M R$ to be made (Table 2). It was found that the minimum oxygen consumption is in all groups similar and constitute $56.0-66.4 \%$ of the mean daily value. On the other hand, maximum oxygen consumption is two times higher than the $A D M R$ value (Table 2). Only in winter this maximum value was considerably lower than in remaining seasons.

\section{Chemical Thermoregulation}

Chemical thermoregulation in S. minutus was measured in overwintered animals in spring and summer and in young animals in summer in the range from 2 to $35^{\circ} \mathrm{C}$ (Table 3 ).

Although oxygen consumption depends on temperature the relationship is not directly proportional. The increase of metabolism is most pronounced in the temperature below $15^{\circ} \mathrm{C}$. In the range of 5 to $15^{\circ} \mathrm{C}$ the change in the metabolism rate amounts to $1.02 \mathrm{cc} / \mathrm{g} \mathrm{hr}$ per $1^{\circ} \mathrm{C}$ when measured in old shrews in spring, or to 0.98 in summer. Young shrews

Table 2

Minimal and maximal oxygen consumption rate in $S$. minutus during daily measurements.

\begin{tabular}{|l|rrr|c|c|c|}
\hline \multicolumn{1}{|c}{ Season \& age } & ADMR & $\begin{array}{c}\mathrm{cc} / \mathrm{g} \mathrm{hr} \\
\text { Min. }\end{array}$ & Max. & $\begin{array}{c}\text { Min.: ADMR } \\
\text { in per cent }\end{array}$ & $\begin{array}{c}\text { Max.: ADMR } \\
\text { in per cent }\end{array}$ & $\begin{array}{c}\text { Max.. } \\
\text { Min. }\end{array}$ \\
\hline Summer, young & 14.88 & 9.07 & 31.11 & 60.9 & 209.1 & 3.43 \\
Autumn, young & 14.10 & 8.37 & 29.13 & 66.4 & 206.6 & 3.50 \\
Winter, young & 14.72 & 8.24 & 25.74 & 56.0 & 174.8 & 3.12 \\
Spring, old & 12.52 & 7.52 & 24.28 & 60.1 & 193.9 & 3.23 \\
Summer, old & 11.24 & 6.99 & 22.15 & 62.2 & 197.1 & 3.17 \\
\hline
\end{tabular}

show a much higher value of $1.26 \mathrm{cc} / \mathrm{g} \mathrm{hr}$ per $1^{\circ} \mathrm{C}$. In the temperature above $15^{\circ} \mathrm{C}$ the metabolism rate decreases in all groups and does not exceed $0.41 \mathrm{cc} / \mathrm{g} \mathrm{hr}$ per $1^{\circ} \mathrm{C}$. The minimum oxygen consumption falls for 25 or $30^{\circ} \mathrm{C}$ and in higher temperatures the metabolism again increases (Table 3).

It should be emphasized that the values obtained in these measurements do not correspond to the rate of basal metabolism, although they probably establish the range of neutral temperatures. Their difference from the basal metabolism is proved by the fact that minimum values obtained in daily runs at $20^{\circ} \mathrm{C}$ are lower even from oxygen consumption at 25 or $30^{\circ} \mathrm{C}$ (cf. Tables 2 and 3). With short-term measurements of oxygen consumption used for estimation of chemical thermoregulation, the shrews are not immobile, and any activity increases oxygen consumption. Thus in order to obtain the lowest metabolism rate at neutral temperature an additional experiment was carried out. 
Oxygen consumption was measured in overwintered shrews in spring at $26^{\circ} \mathrm{C}$ and the behaviour of animals was taken into account. Only the periods of total rest were employed for the calculations. The lowest oxygen consumption estimated in these conditions in two individuals (mean body weight $4.60 \mathrm{~g}$ ) was identical and equal to $7.04 \mathrm{cc} / \mathrm{g} \mathrm{hr}$, or 3.73 $\mathrm{kcal} /$ day. This value is very similar to the minimum value obtained in daily runs, the difference being less than $7 \%$. This small difference may be due to the fact that although daily measurements were carried out at the temperature below the thermoneutral zone the animals could utilize the nest in distinction to shrews examined in short runs. Hence the mi-

Table 3

Oxygen consumption rate during short measurements (15-60 min.) at different seasons.

Average body weight of shrews and number of measurements are given.

\begin{tabular}{|c|c|c|c|c|c|c|c|c|c|c|}
\hline \multirow{2}{*}{\multicolumn{2}{|c|}{$\begin{array}{l}\text { Sea- } \\
\text { son } \\
\text { and } \\
\text { age }\end{array}$}} & \multirow{2}{*}{$\begin{array}{c}\text { Oxygen } \\
\text { consumption }\end{array}$} & \multicolumn{8}{|c|}{ Ambient temperatures, ${ }^{\circ} \mathrm{C}$} \\
\hline & & & 2 & 5 & 10 & 15 & 20 & 25 & 30 & 35 \\
\hline \multirow{8}{*}{ 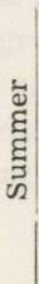 } & & $\mathrm{cc} / \mathrm{g} \mathrm{hr}$ & & 31.21 & 25.15 & 18.59 & 16.68 & 15.05 & 12.40 & 15.46 \\
\hline & $\Xi$ & \pm S.D. & & \pm 0.96 & 1.32 & 1.60 & 1.06 & 0.79 & 0.92 & - \\
\hline & 3 & $\bar{W}$ t., g & & 3.10 & 3.08 & 3.22 & 2.86 & 2.90 & 3.02 & 2.95 \\
\hline & & $\mathrm{n}$ & & 4 & 7 & 7 & 12 & 7 & 6 & 2 \\
\hline & & $\mathrm{cc} / \mathrm{g} \mathrm{hr}$ & 31.01 & 23.84 & 16.98 & 14.01 & 12.92 & 11.93 & 10.45 & 12.31 \\
\hline & 므 & \pm S.D. & & $\begin{array}{r} \pm 1.94 \\
\end{array}$ & 0.88 & 1.07 & 0.94 & 1.06 & 1.12 & - \\
\hline & $\overline{0}$ & Wt., g & 4.65 & 5.00 & 4.95 & 4.83 & 4.95 & 5.10 & 4.98 & 5.06 \\
\hline & & $\mathrm{n}$ & 2 & 6 & 6 & 8 & 9 & 8 & 7 & 4 \\
\hline \multirow{4}{*}{ 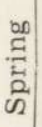 } & & $\mathrm{cc} / \mathrm{g} \mathrm{hr}$ & & 23.16 & 17.13 & 12.97 & 12.20 & 11.44 & 13.17 & \\
\hline & $\gamma$ & \pm S.D. & & \pm 1.36 & 0.66 & 0.78 & 0.57 & 0.89 & - & \\
\hline & $\overline{0}$ & Wt., g & & 4.16 & 4.67 & 4.37 & 4.12 & 4.57 & 4.82 & \\
\hline & & n & & 11 & 8 & 22 & 14 & 6 & 3 & \\
\hline
\end{tabular}

nimum oxygen consumption may be regarded as the value very close to the basal metabolism rate. In those periods shrews remained with certainty in the state of rest.

\section{Social Temperature Regulation}

In order to establish whether S. minutus shows the phenomenon of reduced metabolism in individuals huddling together the oxygen consumption was measured in shrews kept in pairs. It was observed, howver that shrews did not huddle in these conditions and even sometimes showed aggressive behaviour. The results of measurements confirmed these observations and it was found that at $5{ }^{\circ} \mathrm{C}$ oxygen consumption, expressed in $\mathrm{cc} / \mathrm{g} \mathrm{hr}$, was exactly the same in single individuals and in 
pairs. At $15^{\circ} \mathrm{C}$ even the rise of oxygen consumption in pairs of shrews was recorded $(12.97 \mathrm{cc} / \mathrm{g} \mathrm{hr}$ versus $14.65 \mathrm{cc} / \mathrm{g} \mathrm{hr}$ ). This resulted of course from increased activity related to aggressive behaviour. Also in other re-
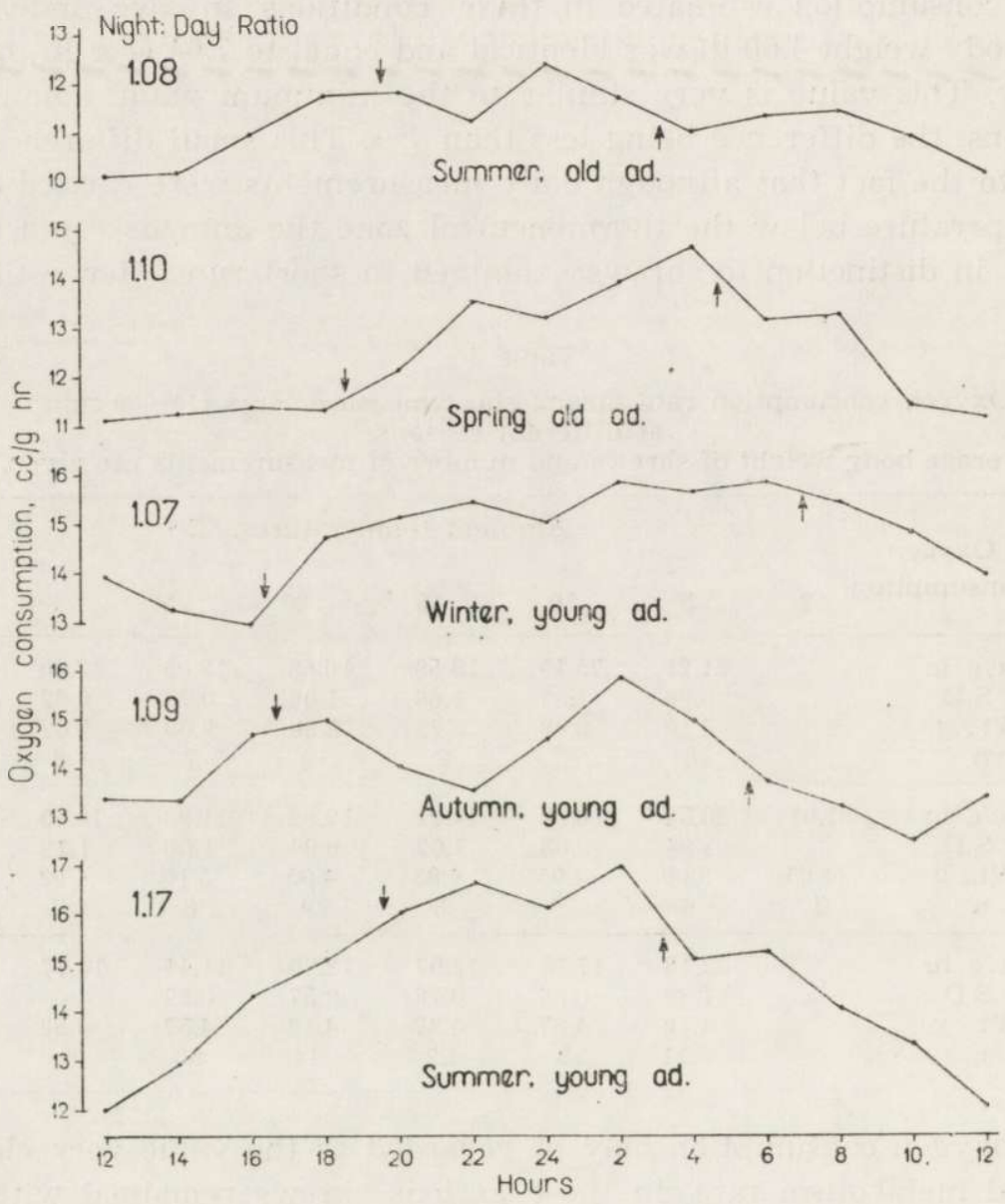

Fig. 1. Daily rhythm of oxygen consumption in S. minutus. Arrows indicate the period of the night.

presentatives of Insectivora - Sorex araneus and Neomys fodiens, no social temperature regulation has been found to exist ( $\mathrm{G} \mathrm{ę} \mathrm{b} \mathrm{c} \mathrm{z} \mathrm{y} \mathrm{ńs} \mathrm{k} \mathrm{i,}$ unpubl. data).

\section{Daily Activity Rhythm}

Daily measurements of oxygen consumption allowed for the establishment of the daily activity rhythm. This rhythm is different depending on 
season and age of the lesser shrew (Fig. 1). The highest activity in young adult shrews in summer was found in the period of night, as indicated by the ratio of oxygen consumption during night and day. On the other hand, in the same season the night: day ratio in old individuals is lower and similar to that found in other seasons. This ratio is only slightly higher in overwintered shrews in spring (Fig. 1).

The obtained data indicate that shrews belong to species active all the day with a slight prevalence of nocturnal activity. Also the pattern of activity is not very distinct and only in old shrews in spring and young shrews in summer one peak of activity may be distinguished. In young animals the activity increases before dusk, with the maximum between hours 22 and 2. In overwintered shrews in spring the peak of activity appearing during the night reaches maximum just before sunrise but stretches also to early morning hours (Fig. 1).

Also in autumn young shrews show a slight increase in activity at the beginning of night and then before sunrise, with a depression in the middle of night, resulting in two small peaks. In overwintered shrews a slight increase of activity is observed around midnight. In all studied groups the minimum activity falls for daily hours and is particularly well marked between hours 10 and 14 (Fig. 1). This minimum is noted even during winter, although then it is impossible to distinguish any peak of activity in other periods of the day.

\section{DISCUSSION}

\section{Metabolism}

The rate of metabolism in the lesser shrew cannot be given as just one value because it undergoes considerable seasonal changes. The energy requirement depends even to a higher degree on the animal age, since in young adult shrews this value is significantly higher than in overwintered animals, and the difference is more pronounced than in the case of S. araneus (G ę bczyński, 1965). The differences in metabolism between young adult and old adult shrews are related not only to body weight because they still exist after computing for metabolic body size. After such recalculation the energy requirement $\left(\mathrm{kcal} / \mathrm{kg}^{0.75}\right)$ is almost identical in all groups of young animals, independently of season. On the other hand, in old adults this value is not only lower than in young ones, but moreover shows seasonal changes, and in summer is lower by $9.7 \%$ than in spring (Table 1).

Hence it may be supposed that in this species, similarly to $S$. araneus (G ę b c z y ńs k i, 1965), physiological reactions undergo changes with age. Acta theriol. 22 
This fact is related to morphological variability depending on changes of internal proportions of the shrew body in different stages of the life cycle ( $\mathrm{Pucek}$, 1965), and may be treated as the adaptation specific for shrews belonging to the genera Sorex and Neomys (P u c e k, 1970).

The results of former investigations on the metabolism of lesser shrew are comparable only in a limited degree. $\mathrm{H}$ a w k in s et al. (1960) after a few consecutive measurements of heat production at $26^{\circ} \mathrm{C}$ in an individual of $4.8 \mathrm{~g}$ body weight concluded that the lowest oxygen consumption amounted to $4.1 \mathrm{kcal} / \mathrm{day}$, on the average. On the other hand, oxygen consumption determined in the present study in two old adult shrews during spring in the state of rest is lower and equal to $3.73 \mathrm{kcal} /$ day. Also $\mathrm{H}$ a w kin s et al. (1960) determined heat production in the active shrew as equal to $6.0 \mathrm{kcal} /$ day, on the average. This result is surprisingly close to $A D M R$ in overwintered shrews in spring ( $5.8 \mathrm{kcal} /$ day), and in summer (6.0 kcal/day).

Unfortunately the data on food intake ( $\mathrm{H} \mathrm{a}$ w k in s \& J e w e ll, 1962) are not comparable to these obtained in the present study since these authors did not estimate the net energy assimilated by $S$. minutes. They concluded only that daily food intake (in kcal per $1 \mathrm{~g}$ body weight) is identical in an old adult in spring and young adult in autumn. When we compare $A D M R$ of shrews in these seasons it appears that oxygen consumption expressed in $\mathrm{kcal} / \mathrm{g}$ body wt. does not show differences. This fact is, of course, insufficient to prove the agreement between the discussed data, but it indicates that their relative ratio is identical in both cases.

The results obtained by $\mathrm{Hawkins}$ et al. (1960) prompted these authors to the conclusion that the metabolism of shrews is not higher than that of rodents, and the difference is in the range expected on the basis of body size alone. A direct comparison of $S$. minutus with a rodent of the same size is of course impossible, but such comparison can be made in respect of common shrew ( $\mathrm{G} \mathrm{ę} \mathrm{bc} \mathrm{z} \mathrm{y} \mathrm{ńs} \mathrm{ki,} \mathrm{1965)} \mathrm{and} \mathrm{harvest} \mathrm{mouse}$ (G ó r e c k i, 1971). The $A D M R$ at $20^{\circ} \mathrm{C}$ in autumn in the common shrew $(7.66 \mathrm{~g})$ amounts to $371 \mathrm{kcal} / \mathrm{kg}^{0.75}$, and in the harvest mouse $(8.71 \mathrm{~g})$ in the same conditions to $291 \mathrm{kcal} / \mathrm{kg}^{0.75}$. The latter value does not deviates from those reported for other rodents but it differs from shrews ( $G$ ę bczynski, 1969). Hence it is impossible to agree with the conclusion that the energy requirement of small insectivores does not differ in any fundamental way from that of small rodents, especially when the metabolism rate of $S$. minutus is still higher. The existence of differences between shrews and rodents is supported by the data on food consumption (H a w kins \& J e we l1, 1962), although these authors held the contrary opinion. 
When $S$. minutus is compared with $S$. cinereus (M or r is on \& P e a rs on, 1946; Morrison \& Dawe, 1959; Buckner, 1964) and Microsorex hoyi (B u c k n e r, 1964) - the shrews of equally small body weight - it appears then that the rate of oxygen consumption is equally high in all three species. Hence it may be supposed that among mammals these species are characterized by extremely high metabolism rate. This fact is related to both small body size and high energy requirement in comparison with rodents.

B a shenina (1965) concluded that the reaction to cold is different in starving $S$. minutus (oxygen consumption changes by $57 \%$ per $1^{\circ} \mathrm{C}$ ) and in fed individuals (oxygen consumption changes by $15.5 \%$ per $1{ }^{\circ} \mathrm{C}$ ). These values would be the highest ones in mammals, but they were confirmed only partially, because no such great differences were observed to exist betwen starving and fed shrews (G ę bczyński, 1971). Nevertheless, the reaction to cold is strongly expressed in S. minutus and amounts to 17 or $18 \%$ per $1{ }^{\circ} \mathrm{C}$, depending on animal age and season.

\section{Activity}

Former investigations on the activity pattern of $S$. minutus demonstrated that these animals are active both during the day and night (Tu pikova, 1949; C row cr of t, 1954; J anský \& Hanák, 1960; $\mathrm{Buchalczyk}$, in print), with a slight predominance of night activity. However, the ratio of night to day activity is in this species lower than in $S$. araneus (Crowcroft, 1954; G ę bczyńs ki, 1965). This is related to a shorter period of staying in the nest ( $\mathrm{T}$ u p i k ova, 1949), because relative food requirement is higher in $S$. minutus than in $S$. araneus.

The period of maximum activity in the lesser shrew is not well established. According to C r ow c r of t (1954) it falls for the day, whereas J a nsk ý \& Hanák (1960) observed that the appearance of maximum activity depends on the day length. The pattern showed two peaks with the maximum between hours 21 and 24 , and between 3 and 6 , while the minimum occurred between hours 9 and 15. Daily measurements of oxygen consumption indicate that the two peak pattern is characteristic only for young adult shrews in autumn, while these animals and old adults in spring show only broad peak of activity (Fig. 1). Nevertheless, in all studied groups the minimum activity falls for the same period as reported by Janský \& Hanák (1960).

Hence there is no doubt that the lesser shrew, although active all the day, shows a definite pattern with the predominance of nocturnal activity. 


\section{REFERENCES}

1. B a sh en in a N. V., 1965: O himičeskoj termoregulacji u melkih nasekomojadnyh (Insectivora, Mammalia). Nauč. Dokl. Vysš. Školy, Biol. Nauki, 4: 43-47.

2. B uchalczyk A., 1972: The locomotory activity of shrews. Acta theriol., 17 (in print).

3. Buckner C. H., 1964: Metabolism, food capacity and feeding behaviour in four species of shrews. Canad. J. Zool., 42: 259-279.

4. Crowcroft P., 1954: The daily cycle of activity in British shrews. Proc. zool. Soc. Lond., 123: 715-729.

5. Dehnel A., 1949: Studies on the genus Sorex L. Annls Univ. M. Curie-Skłodowska, C 4: 17-102 [In Polish with English summ.].

6. Gębczyński M., 1963: Apparatus for daily measurements of oxygen consumption in small mammals. Bull. Acad. Pol. Sci., Cl. II, 11, 9: 433-436.

7. Gębczyński M., 1965: Seasonal changes in the metabolism and activity of Sorex araneus L in n a e s, 1758. Acta theriol., 10, 22: 303-331.

8. G ę b c z y ński M., 1969: Daily heat losses in the Common shrew (Soricidae) in different seasons. [In: "Energy metabolism of farm animals«. Eds. K. L. Blaxter, J. Kielanowski \& G. Thor bek, Europ. Assoc. for Anim. Prod., Publ. No. 12]. Oriel Press Ltd.: 397-400, Newcastle upon Tyne.

9. G ę bc z y ński M., 1971: Oxygen consumption in starving shrews. Acta theriol., 16, 18: 288-292.

10. Górecki A., 1971: Metabolism and energy budget in the harvest mouse. Acta theriol., 16, 15: 213-220.

11. H a wkins A. E. \& J e we 11 P. A., 1962: Food consumption and energy requirements of captive British shrews and the mole. Proc. zool. Soc. Lond., 138, 1: $137-155$.

12. Hawkins A. E., Jewe 11 P. A. \& Tomlinson G., 1960: The metabolism of some British shrews. Proc. zool. Soc. Lond., 135, 1: 99-103.

13. J a n ský L. \& H a ná k V., 1960: Studien über Kleinsäugerpopulationen in Südböhmen. II. Aktivität der Spitzmäuse unter natürlichen Bedingungen. Säugetierk. Mitt., 8, 1/2: 55-63.

14. Morrison P. R. \& Grodziński W., 1968: Morrison respirometer and determination of ADMR. [In: "Methods of ecological bioenergetics«. Eds. W. G r od zińs k i \& R. Z. K le k owsk i]. Polish Acad. Sci.: 153-164. Warszawa-Kraków.

15. Morrison P. R. \& Pears on O. P., 1946: The metabolism of a very small mammal. Science, 104, 2700: 287-292.

16. Morrison P. R., R y ser F. A., \& Dawe A. R., 1959: Studies on the physiology of the masked shrews, Sorex cinereus. Physiol. Zoöl., 32, 4: 256-271.

17. P u cek Z., 1965: Seasonal and age changes in the weight of internal organs of shrews. Acta theriol., 10, 26: 369-438.

18. Pucek Z., 1970: Seasonal and age change in shrews as an adaptive process. Symp. zool. Soc. Lond., 26: 189-207.

19. Tupikova N. V., 1949: Pitanie i harakter sutočnoj aktivnosti zemleroek srednei polosy SSSR. Zool. Ž. 28, 6: 561-572.

20. Wolk E., 1969: Body weight and daily food intake in captive shrews. Acta theriol., 14, 4: 35-47.

Accepted, June 17, 1971.

Mammals Research Institute, Polish Academy of Sciences, Białowieża, woj. Białystok. 


\section{Marek GĘBCZYŃSKI}

\section{TEMPO METABOLIZMU U RYJÓWKI MALUTKIEJ}

\section{Streszczenie}

Zmierzono zużycie tlenu u 76 osobników Sorex minutus Li n nae us, 1776 odławianych w Białowieskim Parku Narodowym, w latach 1963-1964 i 1966-1970. Średni dobowy metabolizm $(A D M R)$ jest wyższy u młodych, niedojrzałych płciowo ryjówek w porównaniu do dojrzałych płciowo przezimków (Tabela 1). Zaznacza się także zróżnicowanie sezonowe, szczególnie wyraźne u przezimków. Przy temperaturze $20^{\circ} \mathrm{C} A D M R$ u osobników młodych wynosi latem $14.88 \mathrm{~cm}^{3} \mathrm{O}_{2} / g$ godz., jesienią odpowiednio 14.10, zimą 14.72. U przezimków ADMR równa się na wiosnę $12.52 \mathrm{~cm}^{3}$ $\mathrm{O}_{2} / g$ godz., a latem 11.24. Najniższy poziom zużycia tlenu notowany w ciągu pomiarów dobowych jest we wszystkich sezonach prawie o połowę niższy od średniej wartości dobowej (Tabela 2). Najniższy zanotowany poziom metabolizmu wyniósł 3,73 kcal/dobę. Zatem tempo metabolizmu u S. minutus jest podobnie wysokie jak u innych ryjówek a tym samym różne w porównaniu z gryzoniami.

Krótkotrwałe pomiary zużycia tlenu w różnych temperaturach wykazały, że u $S$. minutus wzrasta ono.gwałtownie w temperaturach poniżej $15^{\circ} \mathrm{C}$, natomiast w zakresie 20 do $30^{\circ} \mathrm{C}$ ulega niewielkim zmianom (Tabela 3 ).

Dobowe pomiary zużycia tlenu świadczą o tym, że ryjówka malutka należy do gatunków aktywnych całą dobę $\mathrm{z}$ niewielką przewagą aktywności nocnej nad dzienną (Fig. 1). 